\title{
Çocuk Eğitimevindeki Kadın Görevlilerin Sanata Yönelik Görüşlerinin İncelenmesi
}

\author{
Zekiye Çıldır ${ }^{1}$
}

\begin{abstract}
$\ddot{O} z$
Ülkemizde suç işledikten sonra cezası kesinleşen çocuk hükümlülerin, cezalarını esas olarak Çocuk Eğitimevlerinde çekecekleri kanunlarla hüküm altına alınmıştır. Türkiye'de şu anda bir tane çocuk eğitimevi faaliyet göstermektedir. Çocuk Eğitimevlerinde çalı̧̧an kadın görevlilerin kendilerini yetiştirmelerine katkı să̆layacak ve dolayısıyla eğitimevlerinde kalan çocukların topluma kazandırllmasına yardımcı olacak sportif etkinlikler, sanat etkinlikleri ve hobileri kapsayan etkinliklerin kısttlllı̆̆ üzerinde önemle durulması gereken bir konudur. Bu araştırmada Çocuk Eğitimevinde çalışan kadın görevlilerin sanata ilişskin görüşlerinin incelenmesi amaçlanmaktadır. Çalışmada Çocuk Eğitimevinde çalışan kadın görevlilerin sanata yönelik farkındalıklarını saptamak amaçlanmaktadır. Bu bağlamda Çocuk Eğitimevinde çalışan kadın görevlilerin sanatı anlamaları, tepki vermeleri ve estetik duyarlılık olușturmaları amacıyla ileride geliștirilecek sanat eğitimi çalışmalarına uygun ortamı yaratma sürecinde alana katkı sağlanabileceği düşünülmektedir. Araştırma durum saptamasına yönelik betimsel bir çalışma şeklinde desenlenmiştir. Araştırmada durum saptaması ve içerik analizi bir arada kullanılmıştır. Araştırma verileri gerekli resmi izinlerin alınmasıyla Ankara il merkezinde yer alan çocuk eğitimevindeki kadın görevlilere uygulanmak üzere hazırlanan anket formu çözümlenerek elde edilmiştir.
\end{abstract}

Anahtar Kelimeler: Çocuk eğitimevinde çalışan kadın görevliler, Çocuk eğitimevi, Sanat, Yaratıcı drama

\section{Studying the Views of Women in Youth Detention Center Towards Art}

\begin{abstract}
Child convicts whose criminal penalty is confirmed after their criminal process, they are sentenced to spare it in juvenile detention centers under and mainly ruled by the government. In Turkey, there there is currently serving one juvenile detention center. It is an issue to be highlighted that there is an inadequacy of sportive activities, art activities related to various branches, and activities containing various hobbies which will help women working in juvenile detention centers improve themselves and thus integrate children living in juvenile detention centers into society. This research aims to study the views of women working in juvenile detention centers related to art. It is thought that this research is significant in terms of helping women working in juvenile detention centers understand art, give response and create aesthetic sensitivity etc. by using creative drama methods in order to develop an awareness towards art.

The research is designed as descriptive case study. In this research, case study and content analysis will be used together. Research data will be collected by implementing the scale that is prepared beforehand for women working in juvenile detention centers in the center of Ankara province after getting necessary formal permissions. Semi-structured interview method for collecting data, questionnaires and document analysis for material development will be used.
\end{abstract}

Keywords: Women working in juvenile detention centers, Juvenile detention center, Art, Creative drama

1 Blm. Uzm. Ankara Üniversitesi Eğitim Bilimleri Enstitüsü Eğitimin Kültürel Temelleri Anabilim Dalı Güzel Sanatlar Eğitimi Programı Doktora Öğrencisi. Eposta: zcildir@gmail.com 


\section{Giriş}

Sanat, duyuşsal ve bilişsel etkileme gücüne sahip, kültürel bir olgudur. Hayatı anlamamıza, yorumlamamıza ve hayattan zevk almamıza yardımcı olur. İnsanın hayal gücünü yaratıcı kullanmanın bir ürünü olan sanat, insan türüne özgü bir davranıştır. Sanat faydacı bir amaç gütmeden, fiziksel dünyayı semboller vasıtasıyla anlayabilmeyi hedefler. Bir faaliyet ve davranış tarzı olarak, iyi bir insan olmamıza, hayatı anlamlandırmamıza ve şekillendirmemize yarar (Haviland, 2002, s.459). Sanat, eğitimin temel taşlarından biridir. Sanatlar eğitimi en geniş tanımıyla, eğitim bilimlerinin bir dalı olarak estetiğin, sanat tarihinin, eğitim ve öğretim ile ilgili bütün sorunlarılyla ilgilenen süreçtir. Yirminci yüzyılın başından bu yana sanat eğitimi kavramı, kaplamsal ve genel anlamda, güzel sanatların tüm alanlarını ve biçimlerini içine alan, okul içi ve okul dışı yaratıcı sanatsal eğitimi tanımlamaktadır. Dar anlamda ise okullardaki ilgili bölüm ve sınıflarda bu alana ilişkin olarak verilen dersleri tanımlar (San, 1983, s.19). Sanat eğitimi doğası gereği insan odaklıdır, insanı etkinleştirir, güdüler, güven duygusunu geliştirir. Sanatın eğitimsel işlevleri bireysel, toplumsal, kültürel ve ekonomik işlevlerinin sağlıklı düzenli, etkili, verimli bir biçimde gerçekleştirmesini ve gelişmesini sağlayıcı tüm sanatsal öğrenme-öğretme etkinliklerini kapsamaktadır. Sanat eğitiminin hedefleri arasında bireylerin sanattan anlayan bir kişilik kazanmasını sağlamak ve estetik duyarlılığın geliştirilmesine yardımcı olmak yer almaktadır. Sanatlar eğitimi, estetik duyarlılık kazandırmada ilk ve ortaöğretimde en önemli araçlardan biridir. San (2006)'a göre sanat eğitimi “sanatı ve sanatsallı̆̆ devingen değişkenliği içinde kavratan, yaşamsal değerini belirleyen ve yaratıcılığı sanat ve düşün alanında geliştirme amacı taşıyan bir eğitsel programlar bütünüdür. Genel anlamda sanat eğitimi önceden edinilmiş istenmedik davranışları unutma ve terk etme, hatalı davranışları düzeltme işlevi de görür. Son zamanlarda önemi gittikçe artan müzeler ve müze eğitimi konusu sanat eğitiminde değişik ve etkili sanat öğretimi olanakları sunan bir alan olarak karşımıza çıkmaktadır. Müze eğitimi, müzelerin mevcut koleksiyonlarını kullanarak izleyicilerde merak, ilgi ve heyecan uyandıracak ziyaretçi merkezli eğitim programları ve uygulamaya olanak sağlayan etkinlikler hazırlama süreçleri”dir (Talboys, 2006). Sanatın uygarlaştırma ve insancıllaştırma gücüne duyulan inanç, müzelerin eğitim kurumu haline gelmelerinde en önemli etkenlerden birisidir.

Ülkemizde suç işledikten sonra cezası kesinleşen çocuk hükümlülerin, cezalarını esas olarak Çocuk Eğitimevlerinde çekecekleri kanunlarla hüküm altına alınmıştır. Çocuk Eğitimevlerinde öğretmenler, sosyal çalışmacılar, psikologlar, infaz koruma memurları ve idareciler görev yapmaktadır. Türkiye'deki infaz kurumlarında, hükümlülerin eğitimi başlığı altında sürdürülen faaliyetler; okuma yazma kursları, ilkokul ve ortaokul bitirme kursları, lise ve dengi okul bitirme kursları, üniversiteye kayıt ve ceza infaz kurumunda yüksek öğrenim yapma olanağ 1 , meslek eğitimi, tiyatro oynama ve yazma çalışmaları, münazara ve bilgi yarışmaları, film ve video ile eğitim, müzik, folklor kollarının kurularak çalıştırılması, televizyon ve radyo ile eğitim, grup terapisi, bireysel terapi çalışmaları, ferdi görüşmeler, kitap ve kütüphane ile eğitim, psiko-sosyal hizmet programının uygulanması ile eğitim, döner sermaye iş yurtlarında çalışarak meslek öğrenme ve iş ahlakı eğitimi şeklinde sıralanmaktadır (İçli, 1999). Çocuk Eğitimevlerinde gerçekleştirilen eğitim çalışmalarının temelinde yoğunluklu olarak iş ve sanat eğitimi, okul öğretimi yer almaktadır. Suç işleyen çocukların topluma yeniden kazandırılması, olumsuz koşullar sonucu kazanılan istenmeyen davranışların düzeltilmesi ve bireyin yeniden öğrenme sürecinden geçmesi, elverişli sosyal ortamların oluşturulmasıyla gerçekleştirilebilir. Çocuğa verilmesi gereken sanat eğitimi zamanında verilmediği takdirde estetik duyarlılık, sanat eserini koruma, farklı kültürlere değer verme gibi becerilerin kazanılmaması sonucu ortaya çıkabilir. 
Oluşan bu eksikliğin bireyin ileriki yaşamında içinde yaşadığı toplumu da olumsuz etkileyebileceği söylenebilir. Bu olumsuz durumdan sanat eğitimi yoluyla uzaklaşılabilir. Sanat eğitimi "bireylerde değerler sisteminin" oluşmasını sağlayan en önemli kaynaktır. Çocuk hükümlülerin topluma yeniden kazandırılmasında eğitimevlerinde görevli personel de iyileştirme konusunda eğitilmiş ve bilgili olmalıdır. Kurumda çalışan personelin iyileştirme için amaca uygun davranışlarda ve katılımlarda bulunması, istenilen amaca ulaşmanın önemli bir koşuludur. Suç toplumda istenmedik bir davranıştır. $\mathrm{Bu}$ kapsamda kadın görevlilerin (öğretmenler, sosyal çalışmacılar, psikologlar, idareciler ve ceza infaz koruma memurları) gerçekleştirilecek programlı sanat eğitimi uygulamalarına katılımı, çocuğun eğitilerek suç ve suçun sonuçlarından arındırılıp iyi halli olarak topluma yeniden uyumda önemli bir rol oynayacaktır.

Türkiye'deki çocuk eğitimevlerinde gerçekleştirilen sanat eğitimi çalışmaları incelendiğinde ne konular içerisinde, ne de eğitim uygulamaları içerisinde programlı sanat eğitimi etkinliklerinin yer almadığı görülmektedir. Kurumlarda çocuk ve gençlerin enerjilerini olumlu yönlendirerek sağlıklı gelişmelerine, kendilerini yetiştirmelerine ve dolayısıyla topluma kazandırılmalarına yardım edecek sportif etkinlikler, sanatın çeşitli dallarına ilişkin etkinlikler, çeşitli hobileri kapsayan etkinliklerin kısıtlılı̆̆ ve bu alanda çocukları ve gençleri yönlendirecek elemanlarının bulunmaması üzerinde önemle durulması gereken bir başka konudur. Bu bağlamda çocuk hükümlülerle daha çok iletişim halinde olan eğitimevlerindeki kadın görevlilerle (kadın öğretmenler, sosyal çalışmacılar, psikologlar, ceza infaz memurları ve idareciler vb.) sanat eğitimi bağlamında sanat eğitimi etkinliklerinin gerçekleştirilmesi önemli ve gereklidir.

\section{Amaç}

$\mathrm{Bu}$ araştırmanın temel amacı Türkiye'de eğitimevlerinde sanat eğitimi etkinlikleri düzenlenmesine yönelik ihtiyacı kadın görevlilerin görüşleri doğrultusunda saptamak ve değerlendirmektir. Ankara çocuk eğitimevindeki kadın görevlilerin sanata ilişkin görüşlerinin incelenmesine yönelik olarak uzman görüşü alınarak hazırlanan anket verilerinin analizi ile ortaya konacak çözüm önerileri çalışmanın amacını oluşturmaktadır. Bu genel amaç doğrultusunda aşağıdaki soruya yanit aranacaktır.

1.Eğitimevlerinde görevli kadın personelin sanat eğitimine ilişkin görüşleri nelerdir?

$\mathrm{Bu}$ çalışmada, eğitimevlerinde görevli kadın personelin sanat eğitimi etkinliklerine yönelik olumlu yaklaşımlardan hareketle gerçekleştirilecek sanat eğitimi çalışmalarının, suça karışmış çocukların topluma yeniden kazandırılması sürecine olumlu katkı yapacağı düşünülmektedir.

\section{Sinırlılıklar}

1. Adalet Bakanlığı Ceza ve Tevkifevleri Genel Müdürlüğüne bağlı Ankara Çocuk Eğitimevi ve

2. Ankara Çocuk Eğitimevinde Adalet Bakanlığına bağlı olarak çalışan kadın görevliler (kadın öğretmenler, sosyal çalışmacılar, psikologlar, ceza infaz koruma memurları ve idareciler) ile sinırlandırılmıştır. 


\section{Türkiye'deki Çocuk Eğitimevleri}

Çağdaş yaşamın gelişmesinde en önemli olgu eğitimdir. Çocuk suçluluğu üzerine yapılan çalışmalarda da temel yaklaşım eğitimidir. Günümüz toplumunda eğitimin temel amacı bireylere kendini yönetebilme yeteneğini geliştirme yolunda yardımcı olmak, bu yolla gerek toplumun, gerekse bireylerin ödüllendirilmelerini sağlamaktır (Yavuzer, 1982, s. 246). Suça yönelen çocukların da akranları gibi iyi bir eğitim görme hakkı vardır. Suça yönelen çocukların topluma yeniden kazandırılmasında eğitime daha fazla önem verilmelidir. Çocuk Eğitimevleri açık kurumlardır, ceza infaz koruma memurları silahsızdırlar. Kurumların çevresinde koruma duvarı, firarı engelleyici bir yapı yoktur. Kurumlarda barınan çocuklar akranları gibi akademik ve mesleki eğitimlerine kurum dışında devam edebilmektedir. Durumları ve yaşları uygun olanlar ilköğretim, ortaöğretim ve üniversiteye örgün ve ya açık öğretim yoluyla devam edebilmektedir. Okullarında düzenlenen sosyal faaliyetlere, kendilerini geliştirici yabancı dil, bilgisayar, mesleki eğitim vb. kurslara katılabilmekte; tiyatro, konser, müze gezileri gibi sosyal etkinliklere eğitimcilerin gözetiminde katılabilmektedirler.

Türkiye'de suç işlemiş çocukların eğitimine yönelik ilk girişim Galata'daki İskoç Mektebi “Çocuk Kurtarma Yurdu” adı altında, altmış kadar kimsesiz ve suçlu çocuğun barındırılmasıyla 1932 yılında başlamıştır. Çocukların cezalandırılmaları ve yeniden eğitilmeleri amacıyla 1938'de Edirne'de “Çocuk Islahevi” kurulmuştur (Attar, 1992). 1997 yılında İstanbul Bakırköy’de, 1998 yılında Ankara Elmadağ' da sadece çocuklara ait tutukevi açılmıştır (Sözer, 2003). Türkiye'de 1995 yılında başlatılan tretman (iyileştirme) çalışmaları çerçevesinde, Ankara, İzmir ve Elazı̆̆ eğitimevlerinde bulunan iş atölyeleri kapatılmıştır. Yeni uygulamaya göre, örgün öğretime devam etmeleri mümkün olmayan on beş yaşından büyük çocuklar istek ve yetenekleri doğrultusunda uygun mesleğe yönlendirilerek, çıraklıkla ilgili eğitimlere katılmaları sağlanmıştır. Yargılama sonucu özgürlüğünü bağlayıcı ceza alan 12-18 yaş grubu erkek çocuklar ikamet yerlerine göre Ankara, İzmir ve Elazı̆ğ da bulunan çocuk eğitimevlerine, kız çocuklar ise sadece İzmir çocuk eğitimevine gönderilmektedir. Yeni uygulama ile Elazığ ve İzmir illerinde bulunan çocuk eğitimevleri kapatılarak, bu eğitimevlerinde kalan erkek çocuklar Ankara Çocuk Eğitimevinde toplanmıştır. Adalet Bakanlığı web sitesinden alınan bilgilere göre, kız çocuklar İzmir Aliağa Kadın Kapalı kapalı ceza infaz kurumuna nakledilmiştir. Adalet Bakanlığg 2012-2017 mali yatırım programı çerçevesinde İstanbul Ümraniye Çocuk Eğitimevi 2013 Aralık, yeni İzmir Çocuk Eğitimevi 2014 Temmuz, Elazığ Çocuk Eğitimevi 2017 yılında, Erzurum Çocuk Eğitimevi 2014 Kasım'da hizmete sokmayı planlamaktadır.

\section{Çocuk Eğitimevi Nedir?}

Modern çocuk paradigması çerçevesinde çocuğun yetişkinlerden farklı olduğu varsayımından hareket ederek çocuğa özgü yasal ve örgütsel düzenlemeler geliştirilmiştir. Bu düzenlemelerden belki de en önemlisi suça yönelen ve suç işleyen çocuklarla ilgilidir. Gelişmişülkelerde bu çocuklara yönelik bir çocuk adalet sistemi oluşturulmuştur. Bu sistem çocuğun yetişkinlerden ayrı yargılanması ve ayrı kurumlarda yeniden toplumsallaşmasının sağlanması amacıyla kurulmuştur. Bu nedenle, özellikle çocuk suçluluğunda, «iyi edicilik» ve «yeniden eğitim” çalışmaları özel bir önem taşımaktadır.

\section{Ankara Çocuk Eğitimevi}

Ankara Çocuk Eğitimevinin amacı: 12-18 yaş grubu arasında olup işlediği bir fiil sonucu hüküm giymiş olan çocukların yeniden eğitilerek suç ve suçun sonuçlarından arındırılıp iyi halli olarak topluma yeniden kazandırılmasını sağlamaktır. Kurum içinde veya dışında herhangi bir eğitim 
ve öğretim programına devam eden onsekiz yaşını dolduran çocukların eğitim ve öğretimlerini tamamlayabilmeleri için yirmi bir yaşını bitirinceye kadar bu tesislerde kalmalarına izin verilebilir. Ülkemizde "iyi edicilik" ve "yeniden eğitim" çalışmaları, 11-15 ile 15-18 yaşlarındaki tutuklu ve hükümlü gençler için şu an sadece Ankara'da bulunan Çocuk Eğitimevi Müdürlüğünde gerçekleştirilmektedir. Çocuk Eğitimevinde "Yeniden eğitim” çalışmalarının temelinde, iş ve sanat eğitimi ile okul (diploma) eğitim ve öğretimi yer almaktadır. Ankara Çocuk Eğitimevinde ortaokul ve lisenin bulunmaması nedeniyle, hükümlü çocuklar dışarıdaki eğitim kurumlarından yararlanmaktadırlar. Suçlu gençler, bu kurumlarda üretici olmanın verdiği mutluluğun yanında, belirli bir zanaat ve iş dalında ilerleme olanağı bulmaktadırlar. Sözü edilen atölyelerde, çoğunlukla ücretli olarak dışarıdan çalışan sivil ustalardan yararlanılmakta, zaman zaman yetişkin suçlu ustalar da çocukların meslek öğrenmelerine katkıda bulunmaktadırlar. Bu atölyelerin yanında çocuklar, kurum içinde yemek yapma, bulaşık yıkama, kurum temizliğine yardım ve resim gibi türlü faaliyetlerde aktif kılınmaktadır. Ayrıca gençler, boncuk, karton ve tahta malzemeyi kullanmak suretiyle kendi ilgi alanlarında el becerisine dayanan çeşitli hediyelik eşyalar üretmektedirler.

Kurumda bulunan çocuk ve gençlerin suç ayrımı gözetilmeden, eğitim ve öğretimlerine katkıda bulunarak eğitim seviyelerini belli düzeye çıkarmak, mesleki eğitimler sunarak meslek edinmelerine katkıda bulunmak, çocuk ve gençlerin yeniden suç işlemelerini engelleyici etkenleri güçlendirmek ve toplumu suça karşı korumak, çocuk ve gençlerin yeniden toplum içinde sosyalleşmesini teşvik etmek, üretken, kanunlara ve nizamlara saygılı olmalarını sağlamak, çocuk ve gençlerin toplum içinde sorumluluk taşıyan bir yaşam biçimine uyumunu kolaylaştırmaktır.

\section{Eğitimevinde Bulunan Birimler ve Faaliyetleri}

Eğitimevlerinde sosyal hizmetler ve eğitim birimleri bulunmaktadır. Eğitimevlerinde bulunan hükümlü çocuklara bu kurumlarda bulundukları süre içerisinde, kişiliğini geliştirecek, eğitimini güçlendirecek, yeni beceriler elde etmesini, suç işleme eğilimini yok etmeyi sağlayacak ve salıverilme sonrasına hazırlayacak programlar uygulanır. Hükümlü çocuğun yaş, ceza süresi ve yeteneklerine öncelik verilerek ekonomik ve kültür durumuna uygun biçimde düzenlenen eğitim programlar1; temel eğitim, orta ve yüksek öğretim, meslek eğitimi, din eğitimi, beden eğitimi ve kütüphane hizmetleri Eğitim Servisi tarafından sunulmaktadır. Öğretmen yukarıda bahsedilen kriterleri dikkate alarak hükümlü çocuğun kuruma geldiği andan itibaren eğitim ve öğretim ihtiyaçlarını tespit ederek çocuğu uygun eğitim ve öğretim programlarına yönlendirir.

Psiko sosyal yardım servisinde ise, personel ve hükümlülerin ruh ve beden sağllğı ve bütünlüğüne ilişkin koruyucu, geliştirici programları araştıran uygulayan ve gerektiğinde tedavi sürecine katılarak psikolojik destek ve müdahalede bulunan, ayrıca hükümlülerin bireysel özelliklerini, yaşam koşullarını ve suç işleme nedenlerini belirleyerek bireysel gelişmelerine yardımcı olan, kurum yaşamına uyumlarını ve toplumsal yaşamla uyuşmalarını sağlayan ve bireyin yeniden suç işlemesini engelleyecek önlemleri alan ve bu amaçla gerektiğinde kurum en üst amirinin bilgisi dahilinde, aileler ve sosyal çevreyle görüşme yapan bir hizmet vermektedir. İyileştirme programları kapsamında spor alanları, çok amaçlı salon, kütüphane ve iş atölyelerinden yararlanma, meslek edinme kursları gibi faaliyetlere katılabilecek durumdaki hükümlüleri belirlerler. 


\section{Çocuk Suçluluğu ile İlgili Araştırmalar}

Akyüz tarafından 2010 yılında gerçekleştirilen çalışmada çocuğun kültürel hakları ana başlığı altında eğitim hakkı, bilgi edinme ve zararlı yayınlara karşı korunma hakk1, sağlıklı bir çevrede yaşama hakkı, kültürel ve sanatsal etkinliklere katılma hakkı ele alınmaktadır. Çocukların sağlıklı bir ortamda eğitim görme haklarının kapsamı içinde sağlıklı beslenme, fiziksel egzersiz yapma, kültürel ve sanatsal etkinliklere katılma, yeterli dinlenme ve yaralanmalardan korunma yer almaktadır. Fırsat ve olanak eşitliği ile ilgili olarak, fırsat eşitliğinin en önemli olduğu alan olarak eğitim alanı belirtilmektedir. Çocuklar eşit koşullarda eğitilmedikleri taktirde, yetişkin olduklarında eşit koşullarda çalışma ve yaşama olanaklarına sahip olamayacakları ifade edilmektedir (Akyüz, 2010, s.230). Sayıta ve Şirin'in çalışmasında 1slahevlerinde (şu anki kullanımıyla eğitimevi) bulunan çocukların sürdürülen treatman etkinlikleri adlı bölümde, sslahevlerinin açık kurumlar olması sebebi ile, yaş ve eğitim durumu uygun olan çocukların örgün eğitim kurumlarına ve üniversitelere, meslek eğitimi alanların ise çıraklık eğitim merkezine devam edebildikleri anlatılmaktadır. Ayrıca çocukların öğrenimlerine ve geleceklerine olumlu katkılar sağlayabilecek dil, bilgisayar, üniversiteye hazırlık gibi kurslara katıldıkları belirtilmektedir. Bu kurumların çağdaş eğitim anlayışı çerçevesinde yeniden düzenlenme çalışmaları kapsamında, eğitim faaliyetleri ile ilgili yeniliklerin sürdürülmekte olduğunu ifade etmektedir. Islahevinde bulunan çocukların öğrenim görmeye istekli oldukları ancak temel bilgileri az olduğundan okulda zorlandıklarından bahsederek, dikkatleri çabuk dağılan çocukların görsel, işitsel materyallerle zenginleştirilmiş eğitimle daha iyi öğrenebildiklerinden kurumlardaki eğitimin görsel-işitsel eğitim araçları kullanarak daha yararlı olacağını belirtmektedir. Yine eğitim faaliyetleri ile ilgili yenilikler kapsamında, çocuklara hizmet veren personel için yeni bir hizmet içi programı geliştirmek üzere Unicef, Anne Çocuk Eğitim Vakfı ve bazı gönüllü kuruluşlar ile çalışmalara devam edildiği ifade edilmiştir (Sayıta Usta ve Şirin, 2000).

\section{Yöntem}

Çalışma T.C Adalet Bakanlığı Ceza ve Tevkif Evleri Genel Müdürlüğüne bağlı Ankara Çocuk Eğitimevinde 30 Ekim 2013 tarihinde, eğitimevinde görevli kadın personel üzerinde yarı yapılandırılmış anket formu uygulaması şeklinde gerçekleştirilmiştir. Kuruma yapılan ziyaretlerde kadın görevlilerle görüşmeler yapılımış, genel bilgiler alınmıştır. Uygulamanın yapılacağı tarihte kadın görevlilerin (öğretmenler, sosyal çalışmacı, psikologlar, idareciler ve infaz koruma memurları,) anket sorularını herhangi bir etki altında kalmadan yanıtlamalarına olanak sağlayan bir ortam sağlanmıştır. Anket formu doldurulmadan önce kadın görevlilere çalışmanın önemiyle ilgili bilgiler verilmiştir. Sorulara doğru yanıt verilmesinin yapılandırılacak olan sanat eğitimi çalışmalarına ne oranda katkı sağlayacağı anlatılmıştır.

Ankara Çocuk Eğitimevinde serbest zaman değerlendirme etkinlikleri çerçevesinde hobi kursları düzenlenmektedir. El becerileri haline dönüştürülmüş görsel sanat uygulamalarının katılımcılara sanat ruhu vermede ne derece başarılı olduğu tartışmalı bir konudur. Bu tür etkinliklerde katılımcıların gerçek bir sanat dalı ile tanıştırıp, profesyonel bir sanat eğitimi yaklaşımıyla yönlendirilmesi gerekmektedir.

Sanat eğitiminin önceden edinilmiş istenmedik davranışları unutma ve terk etme, hatalı davranışları düzeltme işlevlerinden hareketle, çocuklarla daha fazla iletişim kuran eğitimevinde görevli kadın personelin, suça sürüklenen çocukların topluma yeniden kazandırılmasında önemli bir işlevi vardır. 


\section{Veri Analizi}

Araştırmanın evrenini Türkiye'de bulunan çocuk eğitimevinde çalışan kadın görevliler oluşturmaktadır. Araştırmanın örneklemini ise Ankara il sınırları içinde çocuk eğitimevinde çalışan 14 kadın görevli oluşturmaktadır. Araştırma, çocuk eğitimevinde kadın görevliler üzerinde yarı yapılandırılmış 5 soruluk görüşme formu üzerinden gerçekleştirilmiştir.

\section{Bulgu ve Yorumlar}

Kadın görevlilerin mesleklerinin tespitine yönelik olarak sorulan soruya 1 öğretmen, 1 sosyal çalışmacı, 1 psikolog, 10 infaz koruma memuru ve 1 kişi de diğer cevabını vermişlerdir. Diğer seçeneğini işaretleyen kadın görevlilerden biri seramik kursu eğitmeni olarak görev yapmaktadır.

Anketin birinci sorusunda yer alan "lisans eğitiminiz süresince ne tür sanat eğitimi dersleri aldınız" sorusuna; 3 kişi resim (4 kişi diğer seçeneğinde resim), 2 kişi müzik (4 kişide diğer seçeneğinde müzik), 1 kişi drama (2 kişide diğer seçeneğinde drama), 2 kişi sanat tarihi (3 kişide diğer seçeneğinde sanat tarihi) ve 1 kişi de diğer seçeneğine tezhip, hat, minyatür, ebru, çini, seramik, ahşap, oyma, desen ve tasarım cevaplarını vermiştir. Alınan cevaplar ankete katılanların genel sanat eğitimi kapsamındaki dersleri aldıklarını, bunların yanı sıra geleneksel sanatlara yönelik dersler de aldığ görülmektedir.

Anketin ikinci sorusunda yer alan "eğitim, hizmetiçi eğitim ve iyileştirme faaliyetleri çerçevesinde hangi tür sanat eğitimi programlarına katıldınız” sorusuna; 1 kişi drama atölyesi (1 kişi diğer seçeneğinde drama atölyesi), 1 kişi seramik atölyesi, 1 kişi müzik (2 kişide diğer seçeneğinde müzik), 1 kişi diğer seçeneğine tiyatro, 2 kişi diğer seçeneğinde resim, 1 kişi diğer seçeneğinde tak1 tasarımı, boyama, rölyef, 1 kişi diğer seçeneğine ahşap boyama, 1 kişi de koro cevaplarını verirken, 4 kişi hiçbiri seçeneğini işaretlemişlerdir. Anket katılımcılarından sadece 2 kişi dramaya yönelik hazırbulunuşluğa sahiptir. Diğer seçeneğinde hiçbirini işaretleyenler ise lise, ön lisans ve çeşitli lisans programlarını bitirmiş, ceza infaz koruma memuru olarak görev yapan personeldir. Anketi yanıtlayan bir katılımcının sanat eğitimi programlarına ancak emeklilikten sonra katılabileceğini ifade ederken aslında, sanatın hayatının bir parçası olmadığını ancak emeklilikten sonra yapılacak bir hobi olarak algıladığı sonucu ortaya çıkmaktadır.

Anketin üçüncü sorusunda yer alan eğitim ve iyileştirme faaliyetleri çerçevesinde sanatsal faaliyetlere katıldınız mı sorusuna ise; 7 kişi müze gezisi, 1 kişi ören yeri (açıkhava müzesi) gezisi, 1 kişi resim sergisi, 1 kişi heykel sergisi, 1 kişi seramik sergisi, 1 kişi tiyatro, 2 kişi sinema izleme izleme gibi etkinliklere katıldıklarına ilişkin cevaplar verirken, 4 kişi soruyu cevaplamamıştır. Anketi cevaplayan 8 katılımcı müze ve ören yeri ziyareti yaptıklarını ifade etmişlerdir.

Ankete katılanlar Anketin dördüncü sorusunda yer alan "Kendinizi sanat alanında geliştirmek için ne tür eğitimler aldınız?" sorusuna ise; 3 kişi resim, 2 kişi müzik (1 kişi piyano eğitimi, 1 kişi de ses eğitimi aldığını belirtmiştir), 1 kişi seramik, 1 kişi de tiyatro ve ses eğitimi yanıtlarını vermiştir. 1 kişi herhangi bir eğitim almadığını ifade etmiş, 5 kişi de soruyu cevaplamamıştır.

Anketin beşinci sorusunda yer "Sanat ile ilgili ne tür kitaplar okudunuz?" sorusuna ise katılımcılardan; 1 kişi dünya klasiklerini, 1 kişi roman, 1 kişi mimari ve piyano ile ilgili, 1 kişi internet üzerinden makaleler, 1 kişi görsel kültürler ilgili makale, 1 kişi türkülerle ilgili, 1 kişi sanat tarihi, İslam sanatı ve çeşitli sanat dallarına ilişkin kitaplar okuduklarını belirtmişlerdir. 4 kişi soruyu boş birakmıştır. 
Müzede sanat eğitimi, sanat eğitimi bütünlüğü içerisinde önemli bir alanı oluşturmaktadır. $\mathrm{Bu}$ nedenle çocuk eğitimevinde görev yapan kadın personelin, düzenlenecek sanat eğitimini uygulamalarında çocuklara daha etkin, kalıcı, geçmiş ve gelecek arasında bağ kurmalarına olanak verecek şekilde müzeleri kullanmaları ile gerçekleştirebilecekleri söylenebilir. Müzelerin bu bağlamda ele alınmaması etkin bir sanat eğitimini sınırlandırmış olacaktır. Bundan dolayı çocuk eğitimevi sosyal hizmetler ve eğitim birimi düzenlenecek eğitim etkinliklerinde müzeleri, öğretimde bir yöntem olarak değerlendirebilmelidirler.

\section{Sonuç ve Öneriler}

İnsanın kendini tanıması yaşama ve doğaya en etkin katılımıdır. Sanatın insan yaşamına girmesi toplumda var olan yapının değişmesine katkıda bulunur. Sanatın eğitsel özü ve eğitimsel işlevleri toplumda suçu önleme, azaltma, suçtan uzak durma ve arınma gibi çok yönlü, geniş kapsamlı ve çok seçenekli olanaklar sunmaktadır. Dünyayı anlama ve anlamlandırma sürecinde etkin bir rol oynayan sanat eğitimi örgün ve yaygın eğitimde yeterli düzeyde yer almadığında toplum bundan olumsuz yönde etkilenecektir (İlhan, 2002).

Sanat eğitiminin eğitim kurumları dışında farklı mekânlarda ve uygulamalı olarak yapılabilmesi, eğitiminin daha nitelikli olmasını sağlayabilir. Bu kapsamda eğitim ortamlarının çeşitlendirilmesinde müzeler önemli bir yere sahiptir. Müzelerin sanat eğitiminde iki önemli rolü bulunmaktadır; birincisi müzede sergilenen eserleri anlayıp kavrayabilen, yorumlayan, eleştiren, estetik beğenisi olan izleyici kitlesinin oluşturulması, ikincisi sanat eğitiminin bir diğer amacı olan yaratıcılığın geliştirilmesidir.

Ankara'da şehir merkezi ve ilçelerde 58 adet müze bulunmaktadır. Ankara'daki devlet müzeleri, vakıf müzeleri ya da özel müzelerde müze atölyeleri, çocuk dostu müze, müze odaları, müze gönüllülerinin eğitimine yönelik projeler, farklı müze ve kurumlar tarafından düzenlenen çalıştay, konferans ve seminerler yapılmaktadır. Ankara şehir merkezindeki müzelerin bir bölümü süreli sergi galerileri, fotoğraf galerisi, müze mağazası, konferans ve çok amaçlı salon, sanatçı ikametleri, kafe ve heykel park alanıyla sanatsal çeşitlilik bakımından zengin bir yapıya sahiptir. Ankara'nın ilk çağdaş sanat müzesi olan Cer Modern'in (2010 yılında) açılması önemli bir gelişmedir. Ankara bir diğer çağdaş sanat mekânına, Ulus semtindeki eski Osmanlı Bankası ek binasında Salt Ulus Sanat Galerisi (2013 yılında)'nin açılmasıyla kavuşmuştur. Salt Ulus ve Cer Modern, çocuklara yönelik olarak gerçekleştirilecek sanat eğitini etkinliklerde işbirliği yapma olanağı sağlamaktadır. Ankara için önemli sanat mekânlarından olan Hacettepe Üniversitesi Sanat Müzesi (2005 yılında) Hacettepe Üniversitesi Kültür Merkezi’nde 25 yıldır açılan kişisel, grup ve karma sergilerden, sanatçıların bağışları yoluyla oluşturulmuş bir üniversite müzesidir (Kurt, 2011, s.17). Müzenin Türk Çağdaş Resim Sanatına yönelik geniş bir koleksiyonu bulunmaktadır. Mustafa Ayaz Müzesi ve Plastik Sanatlar Merkezi ise 2009 yılında ziyarete açılmıştır. Sanatçı Mustafa Ayaz'ın kendi olanaklarıyla açtığı müzenin ilk üç katında Ayaz’ın sanatçılığının farklı dönemlerini temsil eden resimler, kara kalem çalışmaları ve heykeller sergilenmektedir. Ankara Vakıf Eserleri Müzesi (2007 yılında) koleksiyonu 13. ve 19. yüzyıllar arası Anadolu halı sanatının en güzel örneklerini, dokumacılığa ait kirman, kirkit, yün tarağı, makas ve iğ örneklerini, el yazmalarını, saatleri, maden eserleri ve ahşap sanatının önemli örneklerini kapsamaktadır. Müzede geçici sergiler kapsamında; minyatür, hat sanatı, cilt sanatı gibi geleneksel el sanatları ve plastik sanatlara ilişkin sergiler de açılmaktadır. Çankaya Belediyesi tarafından işletilen Çağdaş Sanatlar Merkezi (ÇSM) de Ankara'nın önemli sanat 
mekânlarından biridir. ÇSM, şu ana kadar Türk ve Dünya müziğinin önemli isimlerini konuk etmiş, oda müziği konserleri, Türk Sanat Müziği ve Türk Halk Müziği konserlerinin yanı sıra konferanslar, sempozyumlar, film ve tiyatro festivalleri, paneller gibi çok yönlü etkinliklere ev sahipliği yapmıştır. Ankara'da Kültür ve Turizm Bakanlığı Güzel Sanatlar Genel Müdürlüğüne bağlı olan galerilerin sayısı özel girişimlerle birlikte 90'a ulaşmaktadır.

Etike (1996, s.24), sanat tarihi, estetik, sanat eleştirisi gibi disiplinlerin aydın ve uygar insan yetiştirmede önemli görev üstlendiğini ifade etmektedir. Müzelerde gerçekleştirilen uygulamalı çalışmalarda öğrencilerin sanatı uygulama aşamasında edindiği yaşantı, sanatçıyı anlamasını sağlayacak önemli bir alan olarak kabul edilebilir. Bu bağlamda Ankara' daki devlet müzeleri, vakıf müzeleri, özel müzeler ve galerilerde düzenlenen resim, heykel, seramik, çağdaş sanat sergileri, gerçekleştirilecek sanat eğitimi etkinlikleri için zengin bir potansiyele sahiptir.

Yukarıda sayılanlara ek olarak Ankara'da her yıl Nisan ayında Dışişleri Bakanlığı, Kültür ve Turizm Bakanlığı, Milli, Eğitim Bakanlığı'nın desteğiyle Uluslararası Müzik Festivali, Mart ayında Çankaya Belediyesi tarafından düzenlenen Uluslararası Tek Kişilik Oyunlar Festivali'ne ve Uluslararası Ankara Film, Ekim ayının ilk haftasında ise Çankaya Belediyesi tarafından Belgesel Film Günleri düzenlenmektedir. Mayıs ayında Ankara'da düzenlenen Uçan Süpürge Kadın Filmleri Festivali ve Uluslararası Ankara Karikatür Festivali çağdaş sanatla Ankaralı sanatseverlerle buluşturan etkinliklerdir. Ankara'nın kültür ve sanat potansiyeli ve etkinlikleri göz önünde bulundurularak eğitimevinde çalışan kadınların ve suça sürüklenen çocukların topluma hizmet uygulamaları kapsamında bu etkinliklere düzenli olarak katılmaları sağlanmalıdır.

Suça sürüklenen çocuklarla gerçekleştirilecek sanat eğitimi etkinlikleri kapsamında "yaratıcı dramayı" kullanmak önemli bir avantaj sağlayabilir. Birey olma sürecinde sanatın yaşamdaki yerini ve önemini yaşatarak kavratacak biçimde düzenlenmiş programlarla sanatın türlerini, tarihsel gelişimini, ifade gücünü, insanın temel ihtiyaçlarından biri olduğunu uygulamalı çalışmalarla sanatsal yaratma olgunsunu tanımaya yönelik çalışmalar sanat eğitimi çalışmaları olarak ifade edilmektedir. Sanat eğitiminin tanım, kapsam, ilke, amaç ve çalışma alanlarında, özellikle de sanatsal yaratıcılık alanlarında kendini gösteren alan eğitimde yaratıcı dramadır (Adıgüzel, 2002).

Drama yöntemi kullanılarak sanat eğitimi yapılan grup engelli çocuklar olabildiği gibi özgürlükleri kısıtlanmış çocuklar da olabilmektedir. Anadolu Medeniyetleri Müzesi yetkilileri ile yapılan görüşmelerde, 2002 yılında Ankara Çocuk Islahevi Müdürlüğünde (yeni adı ile çocuk eğitimevi) kalan çocukların kültürel etkinlikleri için genel müze gezisi düzenlenerek kültür varlıklarını tanıma ve koruma bilincini vermeye yönelik çalışmalar yapıldığı tespit edilmiştir. Yaratıcı drama, hükümlü çocuklar için ve onlarla iletişim içinde olan meslek gruplarına (sosyal çalışmacı, öğretmen, psikolog, idareciler ve infaz koruma memurları) yönelik drama oturumlarının da yer aldığı sanat eğitim projesi önerilmektedir. Bir disiplin olma boyutunun yanında bir eğitim ve öğretim yöntemi olarak yaratıcı drama, müzelerde düzenlenecek olan sanat eğitimi amacıyla kullanılmaktadır. Düzenlenecek sanat eğitimi etkinliklerine sadece eğitimevlerinde kalan çocuklar değil, eğitimevinde çalışan kadın görevlilerin de etkinliklerinden faydalanmalarını sağlamak çocukları da olumlu yönde etkileyecektir.

Ulucanlar Cezaevi Müzesi örneğinde olduğu gibi kapatılan eski çocuk eğitimevi binaları müze, kültür ve sanat merkezlerine dönüştürülebilir. Oluşturulacak Eğitimevi müzeleri, kurum belleğini yansıtarak suça sürüklenen çocuklar bağlamında Türkiye'deki çocuk kültürü araştırmalarına katkı sağlayacaktır. 
Ankara Çocuk Eğitimevi idarecileri ile yapılan görüşmelerde, eğitimevinde 90 kişinin görev yaptığı tespit edilmiştir. Görev dağılımlarına baktığımızda 1 sosyal çalışmacı, 4 öğretmen, 2 psikolog, 4 idareci ve 60 kişi de infaz koruma memuru olarak görev yapmaktadır. Çalışmanın örneklemini oluşturan kadın görevlilerin sayısına baktığımızda; 1 kadın sosyal çalışmacı, 4 öğretmenden yalnızca 1'i, 2 psikologdan 1'i, 4 idareciden 2'si ve 60 infaz koruma memurundan 8'i kadındır. Çocuklarla her gün iletişim halinde olan bu mesleklerden psikologlar, öğretmenler ve ceza infaz koruma memurlarının daha fazla kadın görevliden oluşması erken yaşta anne şefkatinden mahrum kalan bu çocukların yeniden topluma kazandırılması sürecinde kolaylaştırıcı olacaktır.

\section{Kaynakça}

Adıgüzel, Ö. (2002). Eğitimde Yeni Bir Yöntem ve Disiplin: Yaratıcı Drama. Yaratıcı Drama 1985-1998 Yazllar, Genişletilmiş 2. Baskı. Ankara: Naturel Kitapevi.

Akyüz, Y. (2010). "Çocuk Hukuku” Çocukların hakları ve korunması. Ankara: PegemA Yayınları.

Attar, H. (1992). Suçlu Çocukları Yeniden Eğiten Kurumların Yönetimi. Yayınlanmamış doktora tezi, A.Ü Sosyal Bilimler Enstitüsü, Ankara.

Etike, S., (1996). Sanat Eğitiminde Çocuğa ve Gence Sanattan Anlayan Bir Kişilik Kazanması Hedeflenir. Milli Eğitim Dergisi, 131, s.23-24.

Haviland, W.A. (2002). Kültürel Antroploloji. (H. İnanç ve S. Çiftçi, Çev.) İstanbul: Kaknüs Yayınları.

İçli, T.G. (1999). Türkiye'de Cezaevlerindeki Rehabilitasyon Faaliyetleriyle Illgili Sosyolojik Bir Analiz. Ankara: Adalet Bakanlığı Yayınları.

İlhan, A. (2002). İlköğretimde Değişen Yapı ve Sanat Eğitimi. Ö. Adıgüzel (Yay. Haz.) (2. Bs.). Yaratıcı Drama 1985-1998 Yazllar. Ankara: Naturel Kitapevi.

Kurt, S. (2011). Ankara Müzelerinde Yapılan Eğitim Faaliyetleri. Yayınlanmamış Bitirme Projesi, Ankara Üniversitesi Sosyal Bilimler Enstitüsü, Ankara.

San, İ. (1983). Sanat Eğitimi Kuramları (1. bs.). Ankara: Tan Yayınları.

San, İ. (2006). "Tiyatroya Rağmen Yaratıcı Drama”, Yaratıcı Drama Dergisi, Cilt 1, Sayı 1, 5-12.

Sayıta Usta, S. ve Şirin M.R. (2000). İstanbul Çocuk Raporu. S. Usta Sayıta ve M. R. Şirin (Yay. Haz.). I. İstanbul Çocuk Kurultayı. İstanbul: İstanbul Çocuk Vakfı Yayınları:1

Sözer, M.A. (2003). Çocukların Eğitim Durumları ve Geleceğe İlişkin Beklenti Düzeylerinin Temel Toplumsal Ortamlardan Aldığı Etkiler (Islahevinde Kalan Çocuklar Üzerine Bir Araştırma). Yayımlanmamış Doktora Tezi, Ankara Üniversitesi Eğitim Bilimleri Enstitüsü EPÖ ABD, Ankara.

Talboys, G. (2005). Museum Educator's Handbook, 2.ed. UK: Ashgate Pub Co.

Yavuzer, H. (1998). Çocuk ve Suç (9. bs.). İstanbul: Remzi Kitapevi.

\section{Online Kaynaklar}

Ankara Valiliği Kültür Envanteri sitesinden 1.11.2013 tarihinde erişildi: http://www.envanter.gov.tr/anit/index. http://www.ankarace.adalet.gov.tr/about.html sitesinden 3.11.2013 tarihinde erişildi. 


\section{EK 1: ANKARA ÇOCUK EĞITIMMEVINDEKİ KADIN GÖREVLILERIN SANATA YÖNELİK GÖRÜŞLERINII BELİRLEME ANKETİ}

$\mathrm{Bu}$ anket, araştırmacı tarafından Ankara Çocuk Eğitimevindeki kadın görevlilerin sanata yönelik görüşlerini belirlemeye yönelik olarak hazırlanmıştır. Katılımcıların sanata yönelik görüşlerini belirlemek için hazırlanmış olan ankette 5 soru yer almaktadır. Anketi cevaplarken birden fazla seçenek seçebilirsiniz.

Ankete katılımınızdan dolayı teşekkür ederim.

Zekiye Çıldır*

\section{Kişisel Bilgiler:}

Yaşınız:

Mesleğiniz:

Eğitim Durumunuz:
Lise
( ) Yüksekokul
( ) Üniversite
( ) Lisanüstü
( )

1. Eğitiminiz süresince ne tür sanat eğitimi dersleri aldını?

a. Görsel Sanatlar / Resim

b. Sanat Tarihi

c. Müzik

d. Drama

e. Diğer (açıklar mısınız?)

2. Cezaevinde düzenlenen eğitim ve iyileştirme faaliyetleri çerçevesinde hangi tür sanat eğitimi programlarına katıldınız?

a. Resim atölyesi

b. Seramik atölyesi

c. Drama atölyesi

d. Müzik atölyesi

e. Diğer(açıklar mısınız?).

3. Eğitim ve iyileştirme faaliyetleri çerçevesinde sanatsal faaliyetlere katıldınız mı?

a. Müze Gezisi

b. Ören Yeri (Açıkhava Müzesi) Gezisi

c. Resim Sergisi

d. Heykel Sergisi

e. Seramik Sergisi

f. Sanat Fuarı

g. Tiyatro

h. Sinema

i. Diğer(açıklar mısınız?).

4. Kendinizi sanat alanında geliştirmek için ne tür eğitimler aldınız?

5. Ne tür sanat kitapları okudunuz? (En son hangi kitabı okudunuz?) 